\title{
NILAI-NILAI AKHLAKUL KARIMAH DALAM NOVEL ANAK DI INDONESIA TAHUN 1921-2010
}

\author{
Dewi Budi Purwati \\ Madrasah Aliyah Negeri Insan Cendekia Gorontalo \\ e-mail: dewibudipurwati@yahoo.com
}

\begin{abstract}
Children's literature in Indonesia contains good values or akhlakul karimah which are useful for their education and the elements are relevant to their cognitive, psychological, and language developments. This study aims to identify and find out values of akhlakul karimah in the themes of children's novels in Indonesia in 1921 - 2010 based on the structural approach and values of akhlak from the Islamic perspective. This study employed the qualitative descriptive method using the content analysis. The results of the analysis on the themes of children's novel in $1921-2010$ show that the dominant theme is friendship.
\end{abstract}

Keywords: Indonesian children's novels, values of akhlakul karimah, themes

\section{PENDAHULUAN}

Pendidikan dapat membangun karakter dan jati diri karena terkait dengan perkembangan kognisi, emosi, dan keterampilan anak didik di dunia pendidikan, serta keluarga tidak lepas dari peran karya sastra. Buktinya, sekalipun dalam gempuran budaya elektronik dan dunia maya, sampai saat ini sastra masih digunakan oleh banyak guru dan orang tua sebagai media untuk menanamkan nilai-nilai edukasi, moral, dan akhlak pada anak. Di rumah, setiap malam masih banyak orang tua yang mendongeng dan membacakan bukubuku cerita kepada anaknya sebagai pengantar tidur. Di sekolah, siswa-siswa juga diajar dengan media pengajaran berupa karya sastra (Kurniawan, 2009:1).

Kenyataan tersebut menunjukkan bahwa karya sastra merupakan bagian penting yang tidak bisa dipisahkan dari kehidupan anak. Anak dengan dunianya yang penuh imajinasi menjadi begitu bersahabat dengan sastra (cerita). Lewat sastra, anak bisa mendapatkan dunia yang indah, sederhana, dan nilai pendidikan yang menyenangkan. Hal inilah yang menjadikan sastra sangat efektif untuk menanamkan nilai moral, edukasi, akhlak pada anak.

Dengan melihat arti penting dan pengertian sastra terdapat bukti bahwa karya sastra dapat memberikan solusi untuk dunia pendidikan. Baik untuk penanaman nilai-nilai akhlak maupun pengetahuan intelektual. Oleh karena itu, Nurgiyantoro (2005:vi) mengatakan bahwa penyediaan buku bacaan sastra kepada anak-anak sejak dini, sejak masih bernama anak, diyakini akan membentu literasi dan kemauan membaca anak pada perkembangan usia selanjutnya. Yang lebih penting lagi, dengan cerita (sastra), anak bisa mendapatkan nilai-nilai akhlak mulia yang menunjang perkembangan akhlaknya.

Berdasarkan kenyataan tersebut, penelitian terhadap nilai-nilai akhlak mulia dalam tema novel anak Indonesia sangat penting dilakukan. Penelitian terdahulu yang relevan dengan penelitian ini adalah penelitian yang dilaku- 
kan oleh (1) Dewi Budi Purwati, yang berjudul Nilai-Nilai Akhlak dalam Cerpen Anak Majalah Ummi (skripsi 2002, UNY); (2) Murti Bunanta, yang berjudul Konflik Rumah Tangga dalam Bacaan Anak-Anak Belanda (skripsi 1982, UI); (3) Murti Bunanta, yang berjudul Mark Twain's Adventures of Huckleberry Finn: A Consideration of Rascim and Audience (tesis 1986, UI); (4) Murti Bunanta, yang berjudul Problematika Penulisan Cerita Rakyat untuk Anak Indonesia (disertasi 1997, UI); dan (5) Yuliati Aslami, yang berjudul Nilai Kecerdasan Intrapersonal dan Kecerdasan Interpersonal dalam Novel Di Bawah Lindungan Ka'bah dan Pemanfaatannya sebagai Pembelajaran Apresiasi Sastra (tesis 2009, UPI).

\section{METODE}

Penelitian ini adalah penelitian kualitatif deskriptif dengan teknik analisis konten. Menurut Fraenkel \& Wallen (2007:483) analisis konten adalah suatu teknik yang memungkinkan peneliti untuk mempelajari tingkah laku manusia dengan cara yang tidak langsung, melalui analisis komunikasi mereka, baik yang tertulis maupun lisan (buku, esai, surat kabar, novel, artikel majalah, buku masak, lagu, pidato politik, iklan, gambar) untuk menemukan keyakinankeyakinan, sikap-sikap, nilai-nilai, dan ide-ide dalam komunikasi tersebut. Sedangkan deskriptif kualitatif digunakan untuk mendeskripsikan hasil-hasil analisis terhadap bacaan anak-anak dan penyusunan model pengajaran apresiasi sastra dengan menggunakan hasil analisis.

Menurut Fraenkel \& Wallen (1997:485) langkah-langkah dalam analisis konten adalah sebagai berikut: menentukan tujuan, mendefinisikan istilah-istilah, Menentukan unit analisis, Menemukan data yang relevan; mengembangkan alasan; Mengembang- kan perencanaan sampling; merumuskan kode kategori; reliabilitas dan validitas; dan analisis data.

Pada penelitian ini perlu dilakukan pembatasan masalah yaitu mengenai tema dalam novel anak (1) Si Jamin dan Si Johan karya Mirari Siregar terbitan Balai Pustaka Jakarta cetakan pertama tahun 1921 (yang dianalisis adalah cetakan kedua puluh empat), (2) Sukreni Gadis Bali karya A.A. Pandji Tisna terbitan Balai Pustaka Jakarta tahun 1936 (yang dianalisis adalah cetakan kedua yang sudah disesuaikan untuk bacaan siswa SD dan SMP oleh Huri Yani), (3) Si Dul Anak Jakarta karya Aman Dt. Madjoindo terbitan Balai Pustaka Jakarta tahun 1940 (yang dianalisis adalah cetakan yang kedua puluh dua), (4) Pak Madong karya Junus St. Madjolelo terbitan Balai Pustaka Jakarta 1959 (yang dianalisis adalah cetakan yang keenam), (5) Kisah Petualang Cilik karya Dt. B. Nurdin Jacub terbitan Balai Pustaka Jakarta tahun 1967 (yang dianalisis adalah cetakan yang ketujuh), (6) Anak Gerilyawan karya Marcus terbitan Pustaka Jaya Jakarta tahun 1978 (yang dianalisis adalah cetakan yang kedua), (7) Guruku Matahari Bangsaku karya Dra. Afiah Ismi terbitan Balai Pustaka Jakarta tahun 1982 (yang dianalisis adalah cetakan yang kedelapan), (8) Persahabatan yang Manis karya Bung Smas terbitan CV Redijaya Semarang tahun 1997 (yang dinalaisis cetakan yang keempat), (9A) Si Pitung Superhero Betawi Asli karya Soekanto SA. terbitan DAR! Mizan Bandung tahun 2009, (9B) Berbagi Sahabat karya Masharto Alfathi terbitan Penerbit Mastara Yogyakarta tahun 2009, dan (10) Noval Jadi Batman? Karya Izza H. Fizhah terbitan Mitra Bocah Muslim Yogyakarta tahun 2010 sebagai sampel. Sampel novel-novel tersebut mewakili tahun terbit 1920an, 1930-an, 1940-an, 1950-an, 1960-an, 1970-an, 1980-an, 1990-an, dan 2000-an. 


\section{HASIL DAN PEMBAHASAN}

Struktur narasi novel anak yang dijelaskan di bawah ini adalah tema. Jumlah novel anak yang dianalisis temanya adalah 11, yang mewakili novel anak mulai tahun 1921 sampai 2010. Perkembangan dan tema novel anak tersebut dijelaskan di bawah ini.

\section{Khazanah Perkembangan Novel Anak di Indonesia}

Perkembangan novel anak di Indonesia dari tahun 1921-2010 mengalami perkembangan jumlah yang sangat signifikan. Jumlah pada tahun 1920-an yang hanya satu dua novel anak berkembang menjadi ratusan buku hingga tahun 2000-an untuk setiap terbitannya per tahun. Hal ini dapat dilihat dari grafik berikut.

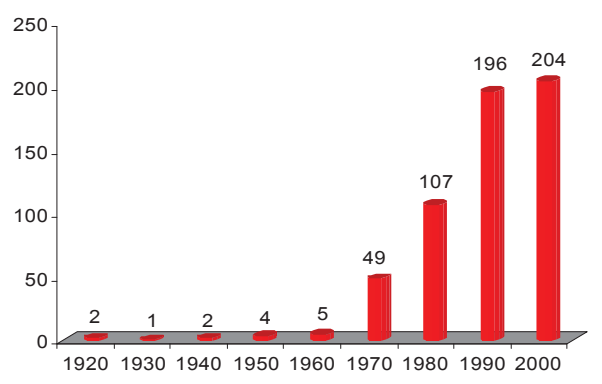

Gambar 3.1 Perkembangan Khazanah Novel Anak di Indonesia Tahun 19212010

Berdasarkan gambar tersebut terlihat dengan jelas perkembangan novel anak di Indonesia pada tahun 1921-2010 sangat signifikan. Diawali dengan jumlah 2 pada tahun 1921 hingga mencapai jumlah 204 novel anak pada tahun 2010 untuk terbitan tiap tahunnya.

Dengan demikian dapat disimpulkan bahwa khazanah novel anak di Indonesia untuk setiap tahunnya mengalami perkembangan jumlah yang sangat signifikan. Perkembangan khazanah novel anak di Indonesia tersebut disebabkan adanya beberapa faktor. Faktor-faktor tersebut adalah bertambahnya jumlah penerbit dan pengarang novel anak per tahun. Faktor berikutnya adalah kepedulian kementerian pendidikan nasional, pusat buku, dan perpustakaan-perpustakaan sekolah di Indonesia dalam pengadaan buku bacaan anak-anak, dalam hal ini novel anak.

\section{Tema Novel Anak di Indonesia}

Tema novel anak yang dijelaskan di bawah ini, berturut-turut adalah $S i$ Jamin dan Si Johan; Sukreni Gadis Bali; Si Dul Anak; Pak Madong; Kisah Petualang Cilik; Anak Gerilyawan; Guruku Matahari Bangsaku; Persahabatan yang Manis; Si Pitung Superhero Betawi Asli; Berbagi Sahabat; dan Noval Jadi Batman?.

\section{Si Jamin dan Si Johan}

Si Jamin dan Si Johan karya Mirari Siregar diterbitkan pada tahun 1921 oleh Balai Pustaka Jakarta. Mirari Siregar mengawali ceritanya dengan betapa sengsaranya dua orang kakak beradik, si Jamin dan si Johan, yang hidup ditindas oleh ibu tirinya. Dari perjuangan dan kasih sayang si Jamin dan si Johan dalam menghadapi kehidupan mereka yang berat, muncullah tema minor berupa ketabahan, persahabatan, kerja keras, kejujuran, pertolongan, dan kesuksesan.

Tema mayor dikembangkan Mirari Siregar melalui kisah hari demi hari kehidupan si Jamin dan si Johan yang sangat sengasara. Betapa sengsaranya si Jamin yang terus dipaksa mengamen oleh ibu tirinya, si Inem. Dan hasil mengamenya digunakan oleh si Inem untuk membeli candu. Bukan hanya itu, sering pula dipukulinya dirinya dan adiknya dalam keadaan perut yang sangat lapar.

Si Jamin dan Si Johan menggambarkan perjuangan dan kasih sayang 
antara si Jamin dan si Johan yang telah ditinggal meninggal dunia oleh ibunya. Kehidupan mereka berubah menjadi sengasara setelah bapak mereka, si Bertes, menikah dengan si Inem yang sangat galak dan pecandu obat-obatan terlarang. Gambaran tersebut merupakan potret kehidupan anak dalam rumah tangga yang kurang bahagia.

Kasih sayang kepada saudara dalam Si Jamin dan Si Johan merupakan tema mayor yang merupakan kategori akhlakul karimah kategori akhlak terhadap keluarga, yakni bersikap baik kepada keluarga.

\section{Sukreni Gadis Bali}

Keadilan Tuhan merupakan tema mayor dalam Sukreni Gadis Bali karya A.A. Pandji Tisna terbitan Balai Pustaka Jakarta 1936. Keyakinan atas adanya keadilan Tuhan merupakan akhlakul karimah yaitu akhlak terhadap Allah SWT. yakni taqwa kepada Allah. Tema minor yang ditemukan dalam Sukreni Gadis Bali adalah adat istiadat Bali, kehidupan di desa, kesedihan, kegagalan, tipu daya, dan persahabatan.

Men Negara yang mempunyai tabiat yang kurang baik. Mulai dari menyembelih babi tanpa izin pemimpin kampung bahkan menggunakan kecantikan anaknya sebagai cara untuk mencari keuntungan dan kesenangan diri.

Dalam Sukreni Gadis Bali, perilaku kurang baik dilakukan oleh Men Negara dan anak gadisnya, Ni Negari. Mereka bersama-sama berusaha untuk memikat pengunjung kedai kopinya dengan kecantikan Ni Negari. Perilakuperilaku Men Negara yang tidak baik diceritakan dengan permainan tema yang mampu menggugah pembaca dengan diiring latar yang sangat hidup, yaitu Bali. A.A. Pandji Tisna menghadirkan Men Negara tampaknya untuk mewakili bahwa di dalam adat istiadat ada warga yang kadang-kadang melanggarnya.

\section{Si Dul Anak Jakarta}

Si Dul Anak Jakarta yang dari cetakan pertama (1940) sampai cetakan keempat masih menggunakan judul Si Dul Anak Betawi (masa sebelum kemerdekaan) karya Aman Dt. Madjoindo diterbitkan oleh Balai Pustaka Jakarta hingga sekarang sudah mencapai cetakan yang ke-22 (2010).

Si Dul Anak Jakarta karya Aman Dt. Madjoindo mempunyai tema mayor berupa berbakti kepada orang tua. Berbakti kepada orang tua merupakan akhlakul karimah kepada keluarga. Tema minor novel anak tersebut adalah keakraban, keggihan dalam usaha, pertengkaran, kesedihan, kesuksesan, dan kegembiraan.

Tema Si Dul Anak Jakarta tidak terlepas dari peran ibu sebagai pendidik utama. Mpok Am, ibunya Si Dul, sangat sayang kepada Si Dul. Kasih sayang ibunya inilah yang akhirnya juga membuat Si Dul sayang dan berbakti kepada orang tuanya.

Berawal dari tema berbakti kepada orang tua yang merupakan bentuk akhlakul karimah terhadap keluarga kemudian oleh Aman Dt. Madjoindo dikembangkan ke tema-tema minor. Kerjasama digambarkan antara si Dul dengan ibunya. Si Dul menjual makanan kecil hasil masakan ibunya. Ibunya yang memasak dan berjualan di rumah, si Dul yang menjajakan sebagian keliling kampung. Tema pertengkaran sepertinya tidak lepas dari dunia anak-anak. Aman Dt. Majdoindo juga memberikan warna pertengkaran dalam ceritanya. Pertengkaran terjadi saat si As dan si Pat sedang bermain. Permainan mereka terganggu oleh ulah Sapii yang nakal. Si dul bermaksud melindung si As dan si Pat, tetapi Sapii marah dan akhirnya 
berkelahi dengan si Dul. Tema minor semakin menghidupkan cerita dengan dibumbui adegan-adegan dan dialogdialog yang jenaka dari para tokoh dengan logat Betawi yang kental.

\section{Pak Madong}

Pak Madong merupakan karya Junus St. Madjolelo yang diterbitkan oleh Balai Pustaka Jakarta pada tahun 1959. Tema mayor yang dibawa oleh pengarang adalah keberanian. Keberanian dalam menegakkan kebenaran dan membantu sesama merupakan akhlakul karimah terhadap Rasulullah SAW. yaitu meneladani Rasulullah SAW. dalam segala aspek kehidupan. Tema minor yang mengiringinya yakni kekeluargaan, kelucuan, dan kebersamaan.

Keberanian Pak Madong, Pak Amat, Ja Tenggeran, Kaki Tiga, Pendekar Sambut, dan pemburu-pemburu lain dari Negeri Simpang Empat, Bukittinggi terlihat dari kebiasaan mereka berburu di hutan. Dari perburuan-perburuan di hutan tersebut, tergambar kebersamaan dan keberanian pemburu asli Sumatera.

Junus St. Madjolelo menunjukkan bahwa keberanian dan kebersamaan selalu terlihat dari para pemburu Sumatera. Keberanian dipunyai para pemburu dengan caranya sendiri. Ada yang menggunakan parang dan senjata khas Sumatera, yakni lading rudus, serta terlihat juga dari permainan silatnya. Kebersamaan para pemburu bukan hanya diceritakan saat mereka berburu di hutan, tetapi juga saat mereka telah kembali ke kampung sebagai warga. Hal ini diceritakan dengan gaya yang sederhana sekaligus kuat pewarnaan kekeluargaannya.

\section{Kisah Petualang Cilik}

Kisah Petualang Cilik Karya Dt. B. Nurdin Jacub terbitan Balai Pustaka Jakarta pada tahun 1967 mengusung tema mayor petualangan. Tema mayor berkembang dengan tema-tema minor yang terdiri atas kejujuran, ketakutan, kegigihan, keinginan dengan usaha, dan pertolongan.

Petualangan digambarkan Dt. B. Nurdin Jacub melalui tokoh Abu yang menemukan sebuaah tas yang berisi uang 5 juta saat mau mencari bapak kandungnya. Tas tersebutlah yang akhirnya dikembangkan menjadi kisah petualangan yang menarik di saat banyak yang menginginkan tas tersebut.

Kalimat-kalimat narasi yang dibangun Dt. B. Nurdin Jacub sangat sederhana, sesuai dengan kemampuan anak-anak untuk membaca, menikmati, dan mengerti jalan ceritanya. Keinginan untuk menyelamatkan tas dan dirinya diimbangi dengan usaha sederhana seorang bocah, yakni berlari dan terus berlari. Saat berpetualang menyelamatkan tas tersebut itulah akhirnya muncul ketakutan pada diri Abu. Takut karena tas yang berisi uang banyak tersebut akan dirampok orang.

Rasa takut tokoh Abu setelah ingat bahwa kata orang kalau orang banyak uang maka akan disamun atau dirampok. Pengolahan tema petualangan yang disukai anak-anak semakin menjadi kisah yang menarik dengan penambahan kejujuran si Abu. Kejujuran tokoh Abu disampaikan Dt. B. Nurdin Jacub dengan bahasa yang tidak menggurui. Akhlak kejujuran terlihat saat tokoh Abu yang menemukan sebuah tas berniat untuk mengembalikan ke pemiliknya. Kisah kejujuran ini akhirnya juga menjadi pembangun tema petualangan sebagai tema mayor cerita tersebut. Kejujuran tokoh Abu merupakan wujud akhlak mulia terhadap diri sendiri, yaitu amanah (jujur).

\section{Anak Gerilyawan}

Anak Gerilyawan karya Marcus AS. Mempunyai tema mayor kesabaran akan mendapatkan hasil. Kemudian, sebagai tema minornya adalah 
perjuangan, kerjasama, kesedihan, dan saling tolong-menolong.

Tema kesabaran dibangun Marcus AS. dengan nuansa zaman kependudukan Belanda di Indonesia. Kesabaran terlihat dari tokoh Amir dan ibunya. Mereka harus bersabar karena ditinggal bapaknya Amir bergerilya melawan Belanda.

Marcus AS. membangun jalinan cerita dalam karyanya dengan nuansa zaman kependudukan Belanda. Tokoh Amir dan ibunya harus rela ditinggal bapak dan suami untuk bergerilya melawan Belanda. Bukan hanya itu, mereka berdua juga harus berpindah-pindah tempat, dari satu kota ke kota lain, dari satu desa ke desa yang lain, untuk mengikuti suaminya di wilayah perjuangannya. Sehingga dari hal tersebut, mereka sering dihina sebagai anak tanpa bapak dan seorang ibu tanpa suami. Kesabaran seorang ibu akhirnya dapat membuat anaknya, Amir, juga menjadi sabar untuk terus menunggu sampai waktunya nanti bertemu ayahnya. Kesabaran Amir dan ibunya tersebut merupakan wujud akhlak terhadap diri sendiri, yakni sabar.

\section{Guruku Matahari Bangsaku}

Novel anak Guruku Matahari Bangsaku karya Dra. Afiah Ismy mempunyai tema mayor penghargaan kepada guru. Tema minor dalam novel ini adalah persahabatan, kerjasama, dan kesederhanaan.

Tokoh Martono yang dulunya adalah murid SD Pak Broto (Bapak) senantiasa memnghormati gurunya walaupun gurunya sudah pensiun. Penghargaan kepada gurunya dia lakukan dengan memberikan perhatian kepada gurunya tersebut dengan mengunjungi dan berkirim surat kepada gurunya. Penghargaan kepada guru merupakan bukti bakti seorang siswa kepada guru sebagai orang tua di sekolah dan di luar sekolah. Berbakti kepada orang tua merupakan wujud akhlak mulia terhadap keluarga, yakni berbakti kepada orang tua.

Afiah Ismy memberikan sentuhan ceritanya dengan masa anak-anak yang terlepas dari persahabatan dan kerjasama. Dan dalam bahasa narasi yang begitu bersahaja, Afiah Ismy memberikan warna kesederhanaan lewat tokoh Pak Broto selaku guru. Sederhana tetapi kaya jiwa.

\section{Persahabatan yang Manis}

Tema mayor Persahabatan yang Manis karya Bung Smas terbitan CV Redijaya Semarangadalah persahabatan. Tema minor yang mengiringi tema mayor adalah penghargaan seorang cucu kepada kakeknya, kerjasama, dan tolong-menolong.

Persahabatan terjalin antara tokoh Pramu dengan Tika. Rasa persahabatan terlihat di saat Tika digigit ular. Pramu dengan rasa kesetiakawanan segera mengejar ular tersebut dan kemudian memeriksa luka Tika.

Narasi lain yang menggambarkan adanya persahabatan dan persaudaraan adalah saat tokoh Tika dengan rasa persahabatannya membantu Pramu untuk mengambilkan air. Persahabatan antara Tika dengan Pramu disuguhkan dalam cerita yang mengalir seperti halnya dunia anak-anak, bermain bersama, belajar bersama, dan bahkan sedikit perselihan yang akhirnya baikan lagi.

Berdasarkan data tersebut dapat disimpulkan bahwa Persahabatan yang Manis karya Bung Smas menampilkan tema mayor yang dekat dengan dunia anak-anak, yaitu persahabatan yang diwarnai dengan kegembiraan, tolongmenolong, dan kerjasama. Persahabatan sendiri merupakan wujud akhlakul 
karimah terhadapa sesama manusia (masyarakat), yakni menjalin persahabatan dan persaudaraan (ukhuwah).

\section{Si Pitung Superhero Betawi Asli}

Tema mayor Si PitungSuperhero Betawi Asli buah karya Soekanto SA. Terbitan DAR! Mizan bandung adalah perjuangan melawan kebatilan. Tema minor yang dapat ditemukan adalah kerjasama, persahabatan, kegigihan, berbakti kepada orang tua dan guru, serta pembelaan kepada rakyat yang lemah.

Dalam novel anak ini, Soekanto SA. mengisahkan betapa kaum kompeni Belanda, tuan tanah, dan tuan sewa berbuat sewenang-wenang terhadap rakyat yang lemah. Kisah perjuangan diawali dari niat si kecil si Pitung yang mau memberantas kesewenang-wenangan yang dilihatnya. Ahkirnya dia berniat belajar pencak silat kepada Haji Naipin demi melawan kebatilan atas kaumnya.

Terlihat bahwa tokoh si Pitung mempunyai semangat yang membara untuk melindungi mereka yang lemah. Semangat ini adalah jiwa yang muncul dari niat yang benar. Benar adalah merupakan wujud akhlak mulia terhadap diri sendiri, yakni benar (as-shidiq).

Soekanto SA. mengobarkan semangat kebajikan, terutama menumpas kebatilan pada zamannya, dengan caranya, yaitu melalui bacaan anak.

\subsubsection{Berbagi Sahabat}

Novel anak Berbagi Sahabat merupakan karya Masharto Alfathi, penderita low vision, yang diterbitkan oleh Mastara Yogyakarta pada tahun 2009. tema mayor novel ini adalah persahabatan. Tema minornya adalah kesedihan, keakraban, saling menolong, kegembiraan, dan saling menghargai.

Dalam novel Berbagi Sahabat, ada dua hal yang menjadi dasar tema ceri- ta, yaitu anak yang tunanetra dan anak yang normal. Berdasarkan perbedaan inilah muncul persahabatan sebagaimana terlihat dari kutipan berikut.

Masharto yang menderita low vision benar-benar mewakili dari anakanak yang menderita cacat, terutama cacat mata. Masharto dengan kalimat-kalimat narasinya senantiasa memberikan sentuhan bahwa anak yang tunanetra juga berhak untuk bersahabat dengan siapa saja, salah satunya dengan anak yang normal. Peristiwa persahabatan terlihat pada saat anak yang buta menjalin persahabatan dengan anak yang melihat. Persahabatan yang disuguhkan Masharto diceritakan dengan gaya yang apa adanya sebagai seorang yang cacat, tanpa malu mengakui bahwa dirinya mempunyai kekurang fisik. Persahabatan yang menjadi tema mayor novel ini merupakan wujud akhlak mulia terhadap sesama manusaia (masyarakat), yakni menjalin persahabatan dan persaudaraan (ukhuwah).

\section{Noval Jadi Batman}

Noval Jadi Batman? karya Izza H. Fizhah (26 tahun) adalah persahabatan. Tema minornya adalah petualangan, kebersamaan, saling menghargai, kegembiraan, dan kejenakaan. Fizhah mengungkapkan bahwa persahabatan terjalin di antara anak-anak, baik ketika mereka di sekolah maupun di luar sekolah. Persahabatan adalah dunia anak-anak yang di sana penuh dengan petualangan tersendiri. Ada warna kebersamaan, saling menghargai, bahkan terkadang penuh dengan kejenakaan.

Tokoh Adit digambarkan berteman karib, bersahabat dengan kedua temannya, yakni Dede dan Noval. Persahabatan ketiga tokoh tersebut terjalin baik di sekolah maupun di luar sekolah. Mereka juga terlihat pulang sekolah juga bersama-sama dengan penuh 
canda. Tema persahabatan ketiga tokoh dalam novel ini diharapkan akan menyampaikan sebuah akhlak mulia terhadap sesama manusia (masyarakat), yakni menjalin persahabatan dan persaudaraan (ukhuwah).

\section{Tema Dominan dalam Novel Anak}

Berdasarkan hasil analisis no- vel-novel anak tersebut maka dapat disimpulkan bahwa tema yang dominan dalam novel anak di Indonesia adalah tema persahabatan. Hal ini sebagaimana terlihat dalam gambar berikut.

Tema merupakan aspek cerita yang sejajar dengan makna dalam pengalaman manusia; sesuatu yang menjadikan suatu pengalaman begitu diingat. Banyak cerita yang menggam-

Tabel 3.1. Daftar Tema Mayor dan Tema Minor dalam Novel Anak

\begin{tabular}{|c|c|c|}
\hline \multirow[t]{2}{*}{ Novel } & \multicolumn{2}{|c|}{ Tema } \\
\hline & Mayor & Minor \\
\hline Si Jamin dan Si Johan & $\begin{array}{l}\text { Perjuangan dan kasih sayang } \\
\text { dua orang kakak beradik }\end{array}$ & $\begin{array}{l}\text { Kesedihan } \\
\text { Ketabahan } \\
\text { Persahabatan } \\
\text { Kerja keras } \\
\text { Kejujuran } \\
\text { Pertolongan } \\
\text { Kegembiraan } \\
\text { Kesuksesan }\end{array}$ \\
\hline Sukremi Gadis Bali & Keadilan Tuhan & $\begin{array}{l}\text { Adat istiadat Bali } \\
\text { Kehidupan di desa } \\
\text { Kesedihan } \\
\text { Kegagalan } \\
\text { Persahabatan }\end{array}$ \\
\hline Si Dul Anak Jakarta & Berbakti kepada orang tua & $\begin{array}{l}\text { Keakraban } \\
\text { Kegigihan dalam usaha } \\
\text { Kesedihan } \\
\text { Kesuksesan } \\
\text { Kegembiraan } \\
\text { Kerjasama } \\
\text { Kejenakaan }\end{array}$ \\
\hline Pak Madong & Keberanian & $\begin{array}{l}\text { Kekeluargaan } \\
\text { Kejenakaan } \\
\text { Kebersamaan } \\
\text { Kekeluargaan }\end{array}$ \\
\hline Kisah Petualang Cilik & Petualangan & $\begin{array}{l}\text { Kejujuran } \\
\text { Ketakutan } \\
\text { Kegigihan } \\
\text { Keinginan dengan usaha } \\
\text { Pertolongan }\end{array}$ \\
\hline Anak Gerilyawan & $\begin{array}{l}\text { Kesabaran akan mendapatkan } \\
\text { hasil }\end{array}$ & $\begin{array}{l}\text { Perjuangan } \\
\text { Kerjasama } \\
\text { Kesedihan } \\
\text { Saling tolong-menolong }\end{array}$ \\
\hline
\end{tabular}




\begin{tabular}{|c|c|c|}
\hline Guruku Matahari Bangsaku & Penghargaan terhadap guru & $\begin{array}{l}\text { Persahabatan } \\
\text { Kesederhanaan } \\
\text { Kerjasama } \\
\text { Perhatian }\end{array}$ \\
\hline Persahabatan yang Manis & Persahabatan & $\begin{array}{l}\text { Penghargaan kepada kakek } \\
\text { Kegembiraan } \\
\text { Kerjasama } \\
\text { Tolong-menolong }\end{array}$ \\
\hline $\begin{array}{l}\text { Si Pitung Super Hero Betawi } \\
\text { Asli }\end{array}$ & Perjuangan melawan kebatilan & $\begin{array}{l}\text { Kerjasama } \\
\text { Persahabatan } \\
\text { Kegigihan } \\
\text { Berbakti kepada orang tua dan } \\
\text { guru } \\
\text { Pembelaan kepada rakyat yang } \\
\text { lemah }\end{array}$ \\
\hline Berbagi Sahabat & Persahabatan & $\begin{array}{l}\text { Kesedihan } \\
\text { Keakraban } \\
\text { Saling menolong } \\
\text { Kegembiraan } \\
\text { Saling menghargai }\end{array}$ \\
\hline Noval Jadi Batman & Persahabatan & $\begin{array}{l}\text { Petualangan } \\
\text { Kebersamaan } \\
\text { Saling menghargai } \\
\text { Kegembiraan } \\
\text { Kejenakaan }\end{array}$ \\
\hline
\end{tabular}

barkan dan menelaah kejadian atau emosi yang dialami manusia seperti cinta, derita, rasa takut, kedewasaan, keyakinan, penghianatan manusia terhadap dirinya sendiri, atau bahkan usia lanjut. Sama seperti makna pengalaman manusia, tema membuat cerita lebih fokus, menyatu, mengerucut, dan berdampak. Bagian awal dan akhir cerita akan pas, sesuai, dan memuaskan berkat keberadaan tema. Adapun cara yang paling efektif untuk mengenali tema sebuah karya adalah dengan mengamati secara teliti setiap konflik yang ada di dalamnya (Stanton, 2007:37-42).

Berdasarkan tabel tersebut dapat disimpulkan bahwa tema, baik mayor maupun minor, yang banyak digunakan dalam novel anak adalah tema persahabatan. Hal ini sesuai dengan teori Stewig
(Suyatno, 2009:80) yang merumuskan bahwa tema sastra anak berkisar pada (1) problem keluarga berupa penerimaan, hubungan dengan anggota keluarga, penerimaan diri sendiri, dan hubungan dengan orang tua, (2) problem di luar keluarga berupa keluarga orang tua tunggal, anak tanpa orang tua, dan perceraian, (3) pengalaman nyata berupa perbedaan fisik dan psikologis, perbedaan sosial dan ekonomi, dan perbedaan geografis, (4) pemahaman perbedaan etnik dan religius. Hal ini dapat dilihat dari diagram berikut ini.

Berdasarkan diagram tersebut dapat disimpulkan bahwa tema dalam novel anak yang sangat dominan adalah tema persahabatan dengan prosentase $28 \%$, selanjutnya adalah tema-tema lain yang prosentasenya masing-masing $9 \%$. 


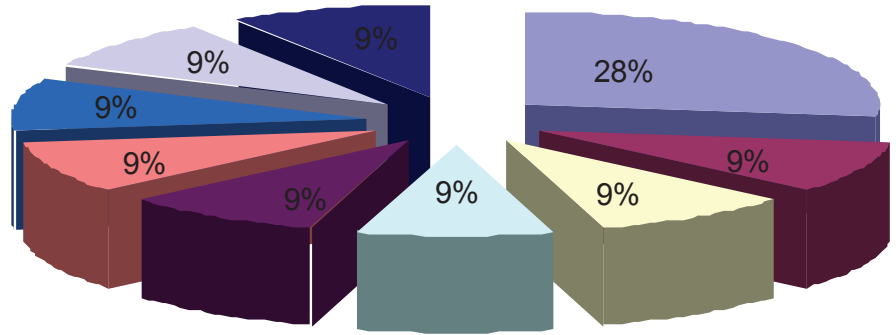

- Perjuangan dan Kasih Sayang

Berbakti kepada Orang Tua

Petualangan

Penghargaan kepada Guru

Perjuangan Melawan Kebatilan
Keadilan Tuhan

Keberanian

Kesabaran

Persahabatan

\section{Gambar 3.2 Tema Novel Anak di Indonesia}

Persahabatan adalah sebuah pengalaman nyata berupa perbedaan fisik dan psikologis, perbedaan sosial dan ekonomi, dan perbedaan geografis, sekaligus sebagai wujud akhlakul karimah yaitu menjalin persahabatan dan persaudaraan (ukhuwah). Tema tersebut menjadi dominan tentunya dengan harapan supaya anak-anak dari kecil sudah berinteraksi dengan temantemannya dan saling menghargai satu sama lain.

Allah SWT. menciptakan manusia bersuku-suku dan berbangsa-bangsa dengan tujuan agar manusia dapat menjalin persaudaran satu dengan yang lainnya. Allah SWT. telah berfirman:

"Sesungguhnya orang-orang mukmin adalah bersaudara, karena itu damaikanlah antara kedua saudaramu dan bertakwalah kepada Allah supaya kamu mendapat rahmat." (Q.S. Al-Hujarat:10).

\section{SIMPULAN}

Khazanah novel anak di Indonesia merupakan sumber karya sastra yang dapat dimanfaatkan nilai-nilai akhlak mulia di dalamnya untuk pengajaran apresiasi sastra. Novel anak mulai dari tahun 1921-2010 terhitung adanya 603 novel anak yang diterbitkan oleh penerbit-penerbit di Indonesia. Khazanah novel anak di Indonesia tersebut dapat dilihat beberapa penerbit yang tetap eksis dari tahun 1921-2010, yakni penerbit Balai Pustaka Jakarta, Gramedia Jakarta, dan Pustaka Jaya Jakarta. Hasil analisis terhadap nilai-nilai akhlakul karimah dalam tema, baik mayor maupun minor, novel anak di Indonesia tahun 1921-2010 yang dominan digunakan adalah tema persahabatan.

Karya sastra dapat memberikan solusi untuk dunia pendidikan, baik untuk penanaman nilai-nilai akhlak maupun pengetahuan intelektual. Oleh karena itu, penyediaan buku bacaan sastra kepada anak-anak sejak dini, sejak masih bernama anak, diyakini akan membantu literasi dan kemauan membaca anak pada perkembangan usia selanjutnya. Tujuan utama dalam cerita (sastra) anak adalah anak bisa mendapatkan nilai-nilai akhlak mulia, seperti persahabatan atau persaudaraan, yang menunjang perkembangan akhlaknya. 


\section{UCAPAN TERIMA KASIH}

Artikel ini diangkat dari penelitian tesis di Program Studi Pendidikan Bahasa Indonesia Sekolah Pascasarjana Universitas Pendidikan Bandung. Ucapan terima kasih di sampaikan kepada Prof. Yus Rusyana dan Prof. Iskandarwassid, M.Pd. selaku Pembimbing Tesis, Ibu Dr. Vismaia Sabariah Damaianti, M.Pd. selaku Kaprodi Pendidikan Bahasa Indonesia SPs UPI, Ibu Wiyatmi, M.Hum. dan Bapak Anwar Effendi, M.Si., dan kepada mitra sejawat yang telah membantu kegiatan verifikasi dan triangulasi data serta hasil penelitian.

\section{DAFTARA PUSTAKA}

Ahmadi, Abu dan Noor Salimi. 2008. MKDU: Dasar-Dasar Pendidikan Agama Islam: Untuk Perguruan Tinggi. Jakarta: Bumi Aksara

Anwar, Rosihan. 2008. Akidah Akhlak. Bandung: CV Pustaka Setia

Arikunto, Suharsimi. 2006. Prosedur Penelitian: Suatu Pendekatan Praktik. Jakarta: PT Rineka Cipta

Ary, Donald, dkk. 2004. Pengantar Penelitian dalam Pendidikan. Terjemahan Arief Furchan. Yogayakarta: Pustaka Pelajar

Aslami, Yuliati. 2009. Nilai Kecerdasan Intrapersonal dan Kecerdasan Interpersonal dalam Novel Di Bawah lindungan Ka'bah dan Pemanfaatannya sebagai Pembelajaran Apresiasi Sastra. TesisProdi Bahasa Indonesia UPI. Tidak diterbitkan.

Creswell, John W. 2008. Educational Research: Planning, Conducting, and Evaluating Quantitative and Qualitative Research. 2008. Australia: PEARSON Merril

Creswell, John W. 1994. Research Design Qualitative \& Quantitative Approaches. United Kingdom: SAGE Publication
Cooper, Donal R. 1997. Metodelogi Penelitian Bisnis. Jakarta: Erlangga

Djiwandono, M.Soenardi. 1996. Tes Bahasa dalam Pengajaran. Bandung: Penerbit ITB

Keesey, Donald. 1994. Context of Criticism. London: Mayfield Publishing Company

Fakultas Bahasa dan Seni UNY. 2008. Bahasa dan Sastra: Dalam Berbagai Perspektif. Yogayakarta: Tiara Wacana

Fraenkel, Jack R dan Norman E. Wallen. How to Design and Evaluate Research in Education. New York: The Mc Graw

Gall, Meridith D., dkk. 2003. Educational Research an Introduction. Boston: PEARSON Education Inc

Gunatama, Gede. 2006. Buku Ajar Puisi (Teori, Apresiasi, dan Pemahaman) . Singaraja : UNDIKSHA Singaraja

Gunatama, Gede. 2004. Sastra dan Ilmu Sastra. Singaraja : IKIP Singaraja

Hardjana, Andre.1985 . Kritik Sastra: Sebuah Pengantar. Jakarta : PT Gramedia

Hourihan, Margery. 1997. Deconstructing The Hero: Literary Theory and Children's Literature. New York: Routledge

Husaini, Adian. 2010. Pendidikan: Membentuk Manusia Berkarakter dan Beradab. Makalah Seminar Pendidikan Nilai Karakter. Hlm.1-9

Jurdiksastrasia FPBS-UPI. 2009. Bahasa dan Sastra Indonesia di Tengah Arus Global. Bandung: Jurdik Bahasa dan Sastra Indonesia FPBS UPI

Mimin, Haryati. 2007. Model dan Teknik Penilaian Pada tingkat Satuan Pendidikan. Jakarta: Gaung Persada Press

Musthafa, Bachrudin. 2008. Teori dan Praktik Sastra: Dalam Penelitian dan Pengajaran. Bandung: SPs UPI dengan New Concept English Education Centre 
Natia. 1985. Ikhtisar Teori Sastra Indonesia. Surabaya: Sinar Wijaya

Nazir, Moh. 2003. Metodelogi Penelitian. Jakarta: Ghalia Indonesia

Nodelman, Perry. 2008. The Hidden Adult: Defining Children's Literature. Baltimore: The Johns Hopkins University Press

Nurgiyantoro, Burhan. 2009. Penilaian dalam Pengajaran Bahasa dan Sastra. Yogyakarta: BPFE Yogyakarta

Nurgiyantoro, Burhan. 2009. Teori Pengkajian Fiksi. Yogyakarta: Gadjah Mada University Press

Nurhadi. 1987. Membaca Cepat dan Efektif. Bandung: CV Sinar Baru

Rachman, Arief. 2010. Urgensi Pendidikan Karakter dalam Membangun Bangsa. Makalah Seminar Pendidikan Nilai Karakter. Hlm. 1-4

Rosyidi, M.Ikhwan, dkk. 2010. Analisis Teks Sastra. Yogyakarta: Graha Ilmu

Santrock, John W. 2007. Child Development. Eleventh Edition. Dallas: University of Texas

Sarumpaet, Riris K. Toha. 2010. Pedoman Penelitian Sastra Anak. Edisi Revisi. Jakarta: yayasan Pustaka Obor Indonesia

Sauri, Sofyan. 2010. Membangun Bangsa Berkarakter Nilai Iman dan Takwa dalam Pembelajaran. Makalah Seminar Pendidikan Nilai Karakter. Hlm. 1-15

Schumcher, Sally dan James H. Mc. Millan. 2001. Research in Educational a Conceptual Introduction. New York: Longman

Seloka Sudiara, Nyoman. 2005. Modul kritik sastra. Singaraja : IKIP Negeri Singaraja

Singarimbun, Masri dan Sofian Efendi. 1982. Metode Penelitian Survai. Jakarta: LP3ES
Slavin, Robert E. 2006. Educational Psycology: Theory and Practice 1. Boston: Pearson Education Inc.

Slavin, Robert E., 2006. Educational Psycology: Theory and Practice 2. Boston: Pearson Education Inc.

Sukmadinata, Nana Syaodih. 2009. Metode Penelitian Pendidikan. Bandung: PT Remaja Rosdakarya

Supranto. 1991. Metodelogi Riset. Jakarta: FE UI

Sutresna, Ida Bagus. 2006. Prosa Fiksi. Singaraja : Undiksha Singaraja

Suyatno, 2009. Struktur Narasi Novel Karya Anak. Surabaya: Jaring Pena

Tarigan, Henry Guntur. 1995. DasarDasar Psikosastra. Bandung: Penerbit Angkasa

Tarigan, Henry Guntur. 1994. Membaca Ekspresif. Bandung: Penerbit Angkasa

Tarigan, Henry Guntur. 2008. Membaca: Sebagai Suatu Keterampilan Berbahasa. Bandung: Penerbit Angkasa

Tampubolon, DP. 2008. Kemampuan Membaca: Teknik Membaca Efektif dan Efisien. Bandung: Penerbit Angkasa

Teeuw, A. 1988. Sastra dan Ilmu Sastra: Pengantar Teori Sastra. Jakarta: PT Dunia Pustaka Jaya

Tomlinson, Carl M. Dan carol LynchBrown. 1996. Essentials of Children's Literature. 2ndedition. Boston: Allyn and Bacon

Wellek, Rene, dan Austin Warren. 1977. Theory of Literatura. New York: Harcourt, Brace \& World, Inc. (Terjemahan dalam Bahasa Indonesia oleh Melani Budiyanto. 1995. Teori Kesusastraan. Jakarta: Gramedia.)

Zainuddin dan Muhammad Jamhari. 1999. Al-Islam 2: Muamalah dan Akhlak. Bandung: CV Pustaka Setia 